\section{Influence of Micro-organisms on the Distribution in Roots of Phosphate labelled with Phosphorus-32}

Micro-organisms have been shown to affect profoundly the uptake of phosphate by plant roots, especially from dilute solutions ${ }^{1-6}$. The way in which they influence the distribution of phosphate between different tissues of roots has now beon examined in autoradiographs.
It is thus evident that unless plants are grown under rigidly sterile conditions the observed distribution of phosphate between the root cortex and other tissues cannot be regarded as resulting solely from the metabolism of the plant. The extent to which the distribution of other ions is influenced by micro-organisms is not known, but a number of investigations have shown patterns of accumulation which are compatible with the view that microbial effects could be at least a contributory factor; for example, highly localized sites of accumulation of caesium in young
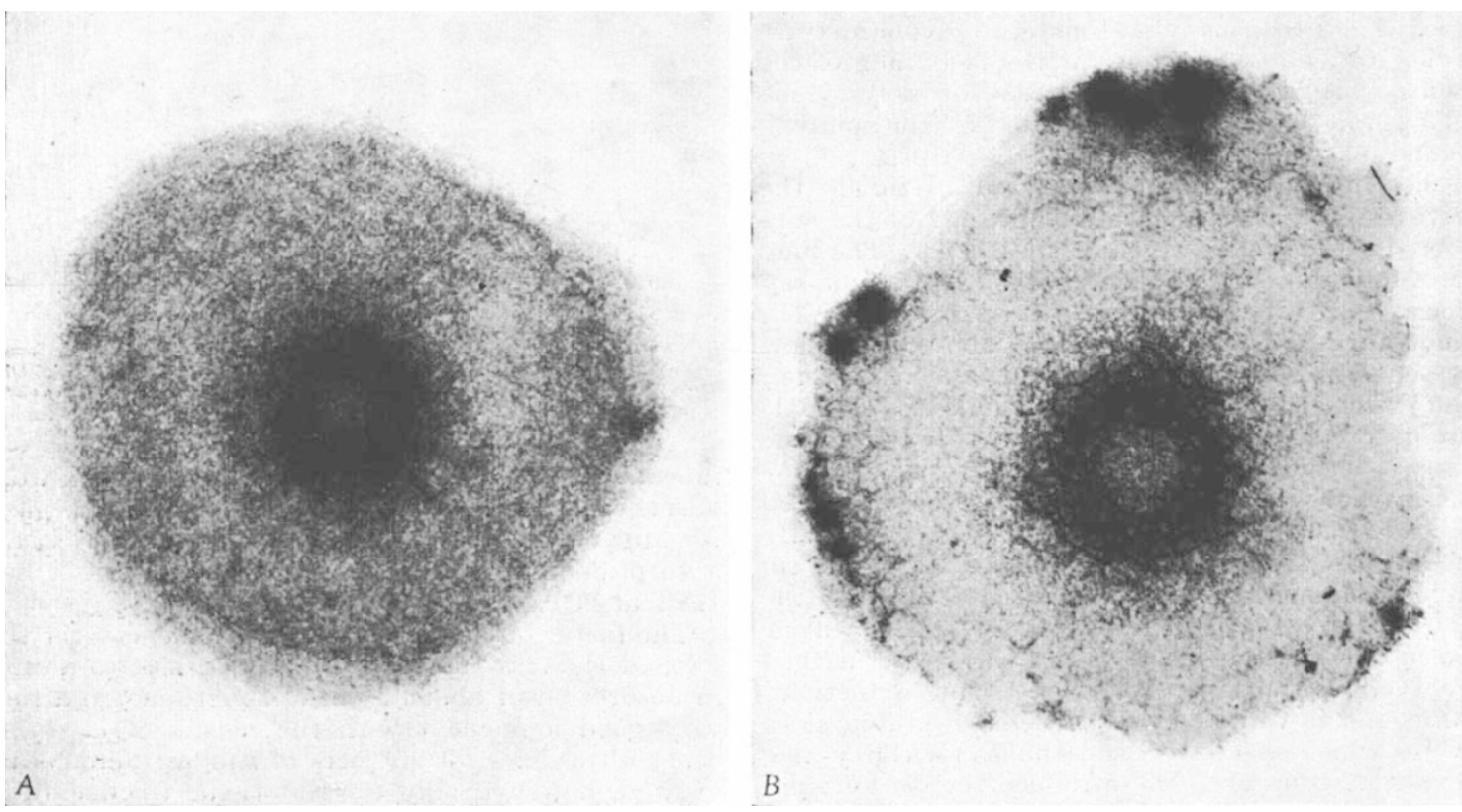

Fig. 1. Autoradiographs showing the distribution of phosphate in transverse sections of roots from barley plants which had been supplied for $6 \mathrm{~h}$ with $3 \times 10^{-6}$ molar potassium phosphate containing $1 \mathrm{mc}$. of phosphorus-32/l. $A$, Plant grown in the absence of micro-organisms; $B$, plant infected at the ambient laboratory level.

Fig. 1 shows typical results for transverse sections of roots of 3 week old barley plants which were grown under sterile and non-sterile conditions and which were supplied for $6 \mathrm{~h}$ with $3 \times 10^{-6}$ molar solutions of potassium phosphate containing 1 mc. of phosphorus-32. The procedures for plant culture have been described by Barber ${ }^{4}$; autoradiographs were prepared by the method of Crossett ${ }^{7}$.

In roots which were grown in sterile conditions, phosphate was distributed relatively uniformly throughout the cortex and there was a marked accumulation in the stele. The presence of micro-organisms, however, led to considerable concentration of phosphate in irregular zones close to the root surfaco. These are attributed to the accumulation of the ion in colonies of bacteria, for microscopic examination showed that there was no fungal invasion of the cortex. This accumulation of phosphate in micro-organisms is readily compatible with the observation that nucleic acids account for a considerably larger fraction of the recently absorbed phosphate in infected than in uninfocted roots $\mathrm{s}^{2,3,5}$.

'The extent of microbial infection in the root (Fig. 1B) is likely to be less than the infection which frequently occurs in water culture because, in order to ensure comparability between sterile and non-sterile plants, all the seedlings were initially grown in sterile conditions, infection being brought about by aeration with unfiltered air. Autoradiographs in which the peripheral accumulation of phosphorus-32 was continuous have been prepared by Crossett ${ }^{7}$ from tho roots of maize plants which had becn grown from gormination without any attempt to exclude micro-organisms; he suggested that concentration of the ion in bacteria might be responsible. barley roots ${ }^{8}$ and the concentration of iron in the superficial tissues of pea roots.
D. A. Barber
J. SANDERSON
R. Scott Russfel

ARC Radiobiological Laboratory,

Letcombe Regis,

Wantage,

Berkshire.

Received January 1, 1968.

${ }^{1}$ Bowen, G. D., and Kovira, A. D., Nature, 211, 665 (1966).

¿ Barber, D. A., Nature, 212, 638 (1966).

${ }^{3}$ Rovira, A. D., and Bowen, G. D., A ustral. J. Riol. Sci., 19, 1167 (1966).

- Barber, D. A., J. Exp. Bot., 18, 163 (1967).

Barber, D. A., and Lourhman, B. C. J. Exp. Bot. 18, 170 (1967).

- Barber, D. A., Nature, 215, 779 (1967).

"Crossett, R. N., Nature, 213, 312 (1967).

${ }^{8}$ Steward, F. C., Symp. Soc. Exp. Biol. 8, 393 (1954).

${ }^{\circ}$ Branton, D., and Jacobson, L., Plant Physiol., 3\%, 548 (1962).

\section{MICROBIOLOGY}

\section{Stimulative Vaporization of Phenyl- mercuric Acetate by Mercury-resistant Bacteria}

Phenylmercuric acetate (PMA) has been widely used as a fungicide and as a disinfectant. It is well known that the antibacterial action of mercuric compound results chiefly from their interforence with essential 